\title{
Synthesis, Antimicrobial and Antioxidant Activity of Chalcone Derivatives Containing Thiobarbitone Nucleus
}

\author{
Talavara Venkatesh ${ }^{1}$, Yadav D Bodke ${ }^{1 *}$, Kenchappa $\mathbf{R}^{1}$ and Sandeep Telkar \\ ${ }^{1}$ Department of PG Studies and Research in Industrial Chemistry, Jnana Sahyadri, Kuvempu University, Shankaraghatta, Shivamogga, Karnataka, India
} ${ }^{2}$ Department of PG Studies and Research in Biotechnology, Jnana Sahyadri, Kuvempu University, Shankaraghatta, Shivamogga, Karnataka, India

\begin{abstract}
In this paper we reported the synthesis of novel series of 5-[1,3-bis (4- substituted phenyl) prop-2-en-1-ylidene]2-thioxodihydropyrimidine-4,6(1H, $5 \mathrm{H})$-diones $(5 \mathrm{a}-\mathrm{k})$. The target compounds were synthesized by the Knoevenagel condensation of different chalcones (3a-k) with thiobarbituric acid using acetic acid as a catalyst in ethanol. These compounds were screened for their antimicrobial and antioxidant activities. From antimicrobial activity results it was found that compounds $5 \mathrm{e}, 5 \mathrm{i}$ and $5 \mathrm{k}$ displayed good antibacterial and antifungal activity against all tested strains. Further, the selected compounds were studied for docking using the enzyme, Glucosamine-6-phosphate synthase and the compounds $5 \mathrm{a}, 5 \mathrm{e}$ and $5 \mathrm{k}$ have emerged as an active antimicrobial agents with least binding energy (-4.52 and $-4.41 \mathrm{~kJ}$ mol-1). Compounds $5 \mathrm{c}$ and $5 \mathrm{f}$ showed promising free radical scavenging and Fe+2 ion chelating activity.
\end{abstract}

Keywords: Chalcone; Thiobarbituric acid; Knoevenagel condensation; Antimicrobial; Antioxidant; Molecular docking study

\section{Introduction}

The resistance of pathogenic microorganisms to accessible antibiotics, anxiolytics, sedatives, hypnotics and anti-convalsunts is rapidly forming a foremost problem worldwide. On the other hand, prime and opportunistic fungal infections continue to rise rapidly because of the increased number of immune compromised patients [1]. In order to combat this new problem, novel, structurally diverse antibiotic compounds are very much essential [2]. The condensed thiobarbiturates possesses diverse pharmacological profile such as antimicrobial, selective cell adhesion inhibitors and DNA cleavage activities [3]. Additionally, recent literature survey has indicated that barbituric acid derivatives may also act as immune modulators [4,5]. Barbiturate and thiobarbiturate derivatives attracted considerable attention owing to their various biological effects such as inhibiting collagenase-3 (MMP-3) [6], recombinant cytochrome P450 enzymes [7], methionine aminopeptidase-1 (MetAP-1) [8], anti-inflammatory, analgesic [9], CYP19 inhibitory activity, molecular docking [10], cytotoxicity properties [11] and broad spectrum pharmacological properties including hypnotic [12] and sedative [13]. Chalcones are known for their multiple anti-infective activities including antimalarial, antileishmanial, antitrypanosomal, antibacterial, antitubercular, antifungal and antiviral [14-17]. The chalcones are found to possess antioxidant activity; the impact is more acute in developing countries due to non-availability of desired medicines and emergence of widespread drug resistance. Glucosamine-6-phosphate synthase (GlcN-6-P) a key enzyme in cell wall biosynthesis catalyzes the first step in hexosamine biosynthesis, converting D-fructose 6-phosphate into D-glucosamine 6-phosphate using glutamine as the ammonia source [18-20]. GlcN-6-P is a precursor of uridine diphospho-N-acetyl glucosamine from which other molecules containing amino-sugar were derived. One of these products, $\mathrm{N}$-acetyl glucosamine, is an important constituent of the peptidoglycan layer of bacterial cell walls and fungal cell wall. Accordingly, GlcN-6-P serves as a promising target for antibacterial and antifungal drug discovery. Earlier, our research group has synthesized different derivatives of benzofuran bearing barbitone and thiobarbitone moieties [21] and other biologically important heterocyclic compounds [22-27]. These results encouraged us to extend the scope of this methodology to build new systems for improving the activity of these scaffolds.

\section{Experimental}

\section{Materials and methods}

The thiobarbituric acid with $98 \%$ purity was purchased from Sigma Aldrich Company. Melting points were recorded on electro thermal melting point apparatus and are uncorrected. Column chromatography was performed using silica gel (230-400 mesh), silica gel GF254 plates from Merck were used for TLC and spots were identified under ultraviolet radiation. Ethyl acetate: pet ether (1:2) is used as a mobile phase. The FTIR spectra were taken in $\mathrm{KBr}$ pellets $(100 \mathrm{mg})$ using Shimadzu FT-IR spectrophotometer. ${ }^{1} \mathrm{HNMR}$ and ${ }^{13} \mathrm{CNMR}$ spectra were recorded on Bruker $400 \mathrm{MHz}$ spectrometer and chemical shifts are shown in $\delta$ values (ppm) with tetramethylsilane (TMS) as internal standard. LCMS were obtained using C-18 column on Shimadzu, LCMS 2010A, Japan. In antimicrobial activity, the zone of inhibition and in antioxidant activity the $\mathrm{IC}_{50}$ values are expressed as mean $\pm \mathrm{SD}$ of three replicates.

\section{General procedure for the synthesis of benzofuran barbitone} derivatives (5a-k)

The mixture of 1,3-diaryl-2-propen-1-ones (3a-k) $(0.01 \mathrm{~mol})$ and thiobarbituric acid $(0.01 \mathrm{~mol})$ was taken in ethyl alcohol, catalytic amount of $\mathrm{AcOH}$ was added and the reaction mixture was refluxed for $7 \mathrm{~h}$. After the completion of reaction, the reaction mass was cooled to room temperature, poured into crushed ice and neutralized with $\mathrm{NaHCO}_{3}$ solution. The product separated out was filtered, dried and recrystallized using ethanol.

5-[3-(4-Chlorophenyl)-1-phenylprop-2-en-1-ylidene]-2thioxodihydropyrimidine- $4,6(1 \mathrm{H}, 5 \mathrm{H})$-dione $(5 \mathrm{a})$ : Light yellow solid

*Corresponding author: Yadav D Bodke, Department of PG Studies and Research in Industrial Chemistry, Jnana Sahyadri, Kuvempu University, Shankaraghatta-577 451, Shivamogga, Karnataka, India, Tel: +919449140275; E-mail:ydbodke@gmail.com

Received June 21, 2016; Accepted June 25, 2016; Published June 30, 2016

Citation: Venkatesh T, Bodke YD, Kenchappa R, Telkar S (2016) Synthesis, Antimicrobial and Antioxidant Activity of Chalcone Derivatives Containing Thiobarbitone Nucleus. Med chem (Los Angeles) 6: 440-448. doi:10.4172/21610444.1000383

Copyright: (C) 2016 Venkatesh T, et al. This is an open-access article distributed under the terms of the Creative Commons Attribution License, which permits unrestricted use, distribution, and reproduction in any medium, provided the original author and source are credited. 
(EtOH); m.p 268-270 ${ }^{\circ} \mathrm{C}$; IR $\left(\mathrm{KBr}, v \mathrm{~cm}^{-1}\right): 3313(\mathrm{NH}), 1657,1653$ $(\mathrm{C}=\mathrm{O}), 1350(\mathrm{C}=\mathrm{S}) ;{ }^{1} \mathrm{H}$ NMR $\left(400 \mathrm{MHz}, \mathrm{DMSO}-\mathrm{d}_{6}, \delta \mathrm{ppm}\right): 8.95(\mathrm{~s}$, $\mathrm{NH}), 8.30-7.53(\mathrm{~m}, \mathrm{Ar}-\mathrm{H}), 7.10(\mathrm{~d}, \mathrm{CH}), 5.72(\mathrm{~d}, \mathrm{CH}) ;{ }^{13} \mathrm{CNMR}(400$ MHz, DMSO-d,$\delta$ ppm): $178.1(\mathrm{C}=\mathrm{S}), 166.6(\mathrm{C}=\mathrm{O}), 146.8(\mathrm{C}=\mathrm{C}), 133.5$ $(\mathrm{C}-\mathrm{Cl}), 131.2(\mathrm{CH}=\mathrm{CH}), 126.4(2 \mathrm{CH}) ; \mathrm{MS}(\mathrm{LCMS}): \mathrm{m} / \mathrm{z} 368.2\left[\mathrm{M}^{+}\right]$and $370.4\left[\mathrm{M}^{+}+2\right]$.

5-[3-(4-Methylphenyl)-1-phenylprop-2-en-1-ylidene]-2thioxodihydropyrimidine-4,6(1H,5H)-dione (5b): Reddish brown solid (EtOH); m.p. $281-283^{\circ} \mathrm{C}$; IR $\left(\mathrm{KBr}, v \mathrm{~cm}^{-1}\right): 3318(\mathrm{NH}), 1651$, $1650(\mathrm{C}=\mathrm{O}), 1358(\mathrm{C}=\mathrm{S})$; ${ }^{1} \mathrm{H}$ NMR $\left(400 \mathrm{MHz}, \mathrm{DMSO}-\mathrm{d}_{6}, \delta \mathrm{ppm}\right)$ : 8.98 (s, NH), 8.30-7.28 (m, Ar-H), 7.12 (d, CH), $5.62(\mathrm{~d}, \mathrm{CH}), 2.40$ (s, $\left.\mathrm{CH}_{3}\right) ;{ }^{13} \mathrm{CNMR}$ (400 MHz, DMSO-d,$\delta$ ppm): 178.3 (C=S), 167.0 $(\mathrm{C}=\mathrm{O}), 144.8(\mathrm{C}=\mathrm{C}), 131.1(\mathrm{CH}=\mathrm{CH}), 126.2(2 \mathrm{CH}) ; \mathrm{MS}(\mathrm{LCMS}): \mathrm{m} / \mathrm{z}$ $348.3\left[\mathrm{M}^{+}\right]$.

5-[3-(4-Methoxyphenyl)-1-phenylprop-2-en-1-ylidene]-2thioxodihydropyrimidine-4,6(1H,5H)-dione $(5 \mathrm{c})$ : Brown yellow solid (EtOH); m.p. 288-290 ${ }^{\circ} \mathrm{C}$; IR $\left(\mathrm{KBr}, v \mathrm{~cm}^{-1}\right): 3342(\mathrm{NH}), 1659,1656$ $(\mathrm{C}=\mathrm{O}), 1319(\mathrm{C}=\mathrm{S}) ;{ }^{1} \mathrm{H}$ NMR (400 MHz, DMSO-d,$\delta$ ppm): $8.76(\mathrm{~s}$, $\mathrm{NH}), 8.20-7.80(\mathrm{~m}, \mathrm{Ar}-\mathrm{H}), 7.21(\mathrm{~d}, \mathrm{CH}), 5.64(\mathrm{~d}, \mathrm{CH}), 3.80\left(\mathrm{~s}, \mathrm{OCH}_{3}\right)$; ${ }^{13} \mathrm{CNMR}\left(400 \mathrm{MHz}, \mathrm{DMSO}-\mathrm{d}_{6}, \delta \mathrm{ppm}\right): 177.6(\mathrm{C}=\mathrm{S}), 167.8(\mathrm{C}=\mathrm{O}), 145.8$ $(\mathrm{C}=\mathrm{C}), 131.3(\mathrm{CH}=\mathrm{CH}), 126.2(2 \mathrm{CH})$; MS (LCMS): m/z 364.7[ $\left.\mathrm{M}^{+}\right]$.

5-[3-[4-(Dimethylamino) phenyl]-1-phenylprop-2-en-1 ylidene -2-thioxodihydropyrimidine-4,6(1H,5H)-dione (5d): Brown solid (EtOH); m.p 280-282 ${ }^{\circ} \mathrm{C}$; IR ( $\left.\mathrm{KBr}, v \mathrm{~cm}^{-1}\right): 3326(\mathrm{NH}), 1667,1663$ $(\mathrm{C}=\mathrm{O}), 1342(\mathrm{C}=\mathrm{S}) ;{ }^{1} \mathrm{H}$ NMR (400 MHz, DMSO-d,$\delta$ ppm): 8.56 (s, $\mathrm{NH}), 8.10-7.85(\mathrm{~m}, \mathrm{Ar}-\mathrm{H}), 7.08(\mathrm{~d}, \mathrm{CH}), 5.61(\mathrm{~d}, \mathrm{CH}), 2.32\left(\mathrm{~s}, \mathrm{~N}_{\left(\mathrm{CH}_{3}\right.}\right)_{2}$; ${ }^{13} \mathrm{CNMR}\left(400 \mathrm{MHz}, \mathrm{DMSO}-\mathrm{d}_{6}, \delta \mathrm{ppm}\right): 178.1(\mathrm{C}=\mathrm{S}), 167.2(\mathrm{C}=\mathrm{O}), 146.8$ $(\mathrm{C}=\mathrm{C}), 131.1(\mathrm{CH}=\mathrm{CH}), 126.2(2 \mathrm{CH}) ; \mathrm{MS}(\mathrm{LCMS}): \mathrm{m} / \mathrm{z} 377.8\left[\mathrm{M}^{+}\right]$.

5-[3-(4-Chlorophenyl)-1-(4-methoxyphenyl)prop-2-en-1ylidene]-2-thioxodihydropyrimidine-4,6(1H,5H)-dione (5e): Light yellow solid (EtOH); m.p 279-281 ${ }^{\circ} \mathrm{C}$; IR $\left(\mathrm{KBr}, v \mathrm{~cm}^{-1}\right): 3400(\mathrm{NH})$, 1665, $1661(\mathrm{C}=\mathrm{O}), 1313(\mathrm{C}=\mathrm{S}) ;{ }^{1} \mathrm{H}$ NMR (400 MHz, DMSO-d ${ }_{6}, \delta$ ppm): $8.65(\mathrm{~s}, \mathrm{NH}), 8.13-7.51(\mathrm{~m}, \mathrm{Ar}-\mathrm{H}), 7.18(\mathrm{~d}, \mathrm{CH}), 5.67(\mathrm{~d}, \mathrm{CH}), 3.81(\mathrm{~s}$, $\left.\mathrm{OCH}_{3}\right) ;{ }^{13} \mathrm{CNMR}\left(400 \mathrm{MHz}, \mathrm{DMSO}-\mathrm{d}_{6}, \delta \mathrm{ppm}\right): 179.3(\mathrm{C}=\mathrm{S}), 167.1$ $(\mathrm{C}=\mathrm{O}), 146.2(\mathrm{C}=\mathrm{C}), 133.1(\mathrm{C}-\mathrm{Cl}), 131.2(\mathrm{CH}=\mathrm{CH}), 126.4(2 \mathrm{CH}) ; \mathrm{MS}$ (LCMS): $\mathrm{m} / \mathrm{z} 398.00\left[\mathrm{M}^{+}\right]$and $400.02\left[\mathrm{M}^{+}+2\right]$.

5-[1-(4-Methoxyphenyl)-3-(4-methylphenyl)prop-2-en-1ylidene]-2-thioxodihydropyrimidine-4,6(1H,5H)-dione (5f): Yellow solid (EtOH); m.p 274-276 ${ }^{\circ}$; IR $\left(\mathrm{KBr}, v \mathrm{~cm}^{-1}\right): 3395(\mathrm{NH}), 1672,1660$ $(\mathrm{C}=\mathrm{O}), 1365(\mathrm{C}=\mathrm{S}) ;{ }^{1} \mathrm{H}$ NMR (400 MHz, DMSO-d $\left.{ }_{6}, \delta \mathrm{ppm}\right): 8.70(\mathrm{~s}$, $\mathrm{NH}), 8.32-7.53(\mathrm{~m}, \mathrm{Ar}-\mathrm{H}), 7.17(\mathrm{~d}, \mathrm{CH}), 5.68(\mathrm{~d}, \mathrm{CH}), 3.81\left(\mathrm{~s}, \mathrm{OCH}_{3}\right)$, $2.40\left(\mathrm{~s}, \mathrm{CH}_{3}\right) ;{ }^{13} \mathrm{CNMR}\left(400 \mathrm{MHz}, \mathrm{DMSO}-\mathrm{d}_{6}, \delta \mathrm{ppm}\right): 178.6(\mathrm{C}=\mathrm{S})$, $167.5(\mathrm{C}=\mathrm{O}), 146.4(\mathrm{C}=\mathrm{C}), 131.3(\mathrm{CH}=\mathrm{CH}), 126.4(2 \mathrm{CH}) ; \mathrm{LCMS}: \mathrm{m} / \mathrm{z}$ $378.9\left[\mathrm{M}^{+}\right]$.

5-[3-(4-Hydroxyphenyl)-1-(4-methoxyphenyl)prop-2-en-1ylidene]-2-thioxodihydropyrimidine-4,6(1H,5H)-dione $(5 \mathrm{~g})$ : Brown solid (EtOH); m.p 281-283 ${ }^{\circ} \mathrm{C}$; IR $\left(\mathrm{KBr}, v \mathrm{~cm}^{-1}\right): 3446(\mathrm{OH}), 3348(\mathrm{NH})$, 1660, $1654(\mathrm{C}=\mathrm{O}), 1336(\mathrm{C}=\mathrm{S}) ;{ }^{1} \mathrm{H}$ NMR $\left(400 \mathrm{MHz}, \mathrm{DMSO}_{-} \mathrm{d}_{6}, \delta\right.$ ppm): 8.61 (s, NH), 8.30-7.70 (m, Ar-H), $7.16(\mathrm{~d}, \mathrm{CH}), 6.25(\mathrm{~s}, \mathrm{OH})$, $5.68(\mathrm{~d}, \mathrm{CH}), 3.86\left(\mathrm{~s}, \mathrm{OCH}_{3}\right) ;{ }^{13} \mathrm{CNMR}\left(400 \mathrm{MHz}, \mathrm{DMSO}-\mathrm{d}_{6}, \delta \mathrm{ppm}\right)$ : $179.5(\mathrm{C}=\mathrm{S}), 167.5(\mathrm{C}=\mathrm{O}), 146.2(\mathrm{C}=\mathrm{C}), 131.2(\mathrm{CH}=\mathrm{CH}), 126.4(2 \mathrm{CH})$; LCMS: $\mathrm{m} / \mathrm{z} 380.2\left[\mathrm{M}^{+}\right]$.

5-[1-(4-Methoxyphenyl)-3-phenylprop-2-en-1-ylidene]-2thioxodihydropyrimidine-4,6(1H, 5H)-dione $(5 \mathrm{~h})$ : White crystal (EtOH); m.p 285-287 ${ }^{\circ} \mathrm{C}$; IR ( $\left.\mathrm{KBr}, v \mathrm{~cm}^{-1}\right): 3375(\mathrm{NH}), 1674,1672$ $(\mathrm{C}=\mathrm{O}), 1367(\mathrm{C}=\mathrm{S})$; ${ }^{1} \mathrm{HNMR}$ (400 MHz, DMSO-d $\left.\mathrm{d}_{6} \delta \mathrm{ppm}\right): 8.80(\mathrm{~s}$, $\mathrm{NH}), 8.01-7.61-(\mathrm{m}, \mathrm{Ar}-\mathrm{H}), 7.14(\mathrm{~d}, \mathrm{CH}), 5.64(\mathrm{~d}, \mathrm{CH}), 3.88\left(\mathrm{~s}, \mathrm{OCH}_{3}\right)$; ${ }^{13} \mathrm{CNMR}\left(400 \mathrm{MHz}, \mathrm{DMSO}-\mathrm{d}_{6}, \delta \mathrm{ppm}\right): 178.4(\mathrm{C}=\mathrm{S}), 167.3(\mathrm{C}=\mathrm{O})$, $146.6(\mathrm{C}=\mathrm{C}), 131.5(\mathrm{CH}=\mathrm{CH}), 126.4(2 \mathrm{CH}) ; \mathrm{LCMS}: \mathrm{m} / \mathrm{z} 364.7\left[\mathrm{M}^{+}\right]$.
5-[3-(4-Methoxyphenyl)-1-(4-nitrophenyl)prop-2-en-1-ylidene] pyrimidine-2,4,6(1H,3H,5H)-trione (5i): Orange solid (EtOH); m.p 296-298 ${ }^{\circ}$; IR $\left(\mathrm{KBr}, v \mathrm{~cm}^{-1}\right): 3455(\mathrm{NH}), 1671,1668(\mathrm{C}=\mathrm{O}), 1374(\mathrm{C}=\mathrm{S})$; ${ }^{1} \mathrm{H}$ NMR (400 MHz, DMSO-d,$\delta$ ppm): $8.75(\mathrm{~s}, \mathrm{NH}), 8.30-7.51(\mathrm{~m}$, Ar-H), 7.31 (d, CH), 5.75 (d, CH), $3.65\left(\mathrm{~s}, \mathrm{OCH}_{3}\right) ;{ }^{13} \mathrm{CNMR}(400 \mathrm{MHz}$ DMSO- $\left.\mathrm{d}_{6}, \delta \mathrm{ppm}\right): 179.1(\mathrm{C}=\mathrm{S}), 167.3(\mathrm{C}=\mathrm{O}), 146.2(\mathrm{C}=\mathrm{C}), 131.2$ $(\mathrm{CH}=\mathrm{CH}), 126.4(2 \mathrm{CH})$; LCMS: $\mathrm{m} / \mathrm{z}$ 409.33[$\left[\mathrm{M}^{+}\right]$.

5-[3-[4-(Dimethylamino)phenyl]-1-(4-nitro)prop-2-en-1ylidene]-2-thioxodihydropyrimidine- $4,6(1 \mathrm{H}, 5 \mathrm{H})$-dione $(5 \mathrm{j})$ : Light black solid (EtOH); m.p 293-295 ${ }^{\circ} \mathrm{C}$; IR $\left(\mathrm{KBr}, v \mathrm{~cm}^{-1}\right): 3502(\mathrm{NH})$, 1669, $1662(\mathrm{C}=\mathrm{O}), 1388(\mathrm{C}=\mathrm{S}) ;{ }^{1} \mathrm{H}$ NMR (400 MHz, DMSO-d ${ }_{6}, \delta$ ppm): 8.70 (s, NH), 8.32-7.51 (m, Ar-H), $7.24(\mathrm{~d}, \mathrm{CH}), 5.62(\mathrm{~d}, \mathrm{CH})$, $2.42\left(\mathrm{~s}, \mathrm{~N}\left(\mathrm{CH}_{3}\right)_{2} ;{ }^{13} \mathrm{CNMR}\left(400 \mathrm{MHz}, \mathrm{DMSO}-\mathrm{d}_{6}, \delta \mathrm{ppm}\right): 179.6(\mathrm{C}=\mathrm{S})\right.$, $167.3(\mathrm{C}=\mathrm{O}), 146.2(\mathrm{C}=\mathrm{C}), 131.2(\mathrm{CH}=\mathrm{CH}), 126.4(2 \mathrm{CH}) ; \mathrm{LCMS}: \mathrm{m} / \mathrm{z}$ $422.3\left[\mathrm{M}^{+}\right]$.

5 - [ 1,3 - Bis (4-chlorophenyl) prop-2-en- 1 - ylidene ]-2 thioxodihydropyrimidine-4,6(1H,5H)-dione (5k): Yellow solid (EtOH); m.p 272-274 ${ }^{\circ} \mathrm{C}$; IR $\left(\mathrm{KBr}, v \mathrm{~cm}^{-1}\right): 3323(\mathrm{NH}), 1676,1651$ $(\mathrm{C}=\mathrm{O}), 1354(\mathrm{C}=\mathrm{S}) ;{ }^{1} \mathrm{H}$ NMR (400 MHz, DMSO-d6, $\left.\delta \mathrm{ppm}\right): 8.75$ (s, $\mathrm{NH}), 8.30-7.51(\mathrm{~m}, \mathrm{Ar}-\mathrm{H}), 7.10(\mathrm{~d}, \mathrm{CH}), 5.72(\mathrm{~d}, \mathrm{CH}) ;{ }^{13} \mathrm{CNMR}(400$ $\mathrm{MHz}, \mathrm{DMSO}-\mathrm{d} 6, \delta \mathrm{ppm}): 178.1(\mathrm{C}=\mathrm{S}), 167.0(\mathrm{C}=\mathrm{O}), 145.8(\mathrm{C}=\mathrm{C})$, $133.5(\mathrm{C}-\mathrm{Cl}), 131.2(\mathrm{CH}=\mathrm{CH}), 126.4(2 \mathrm{CH})$; LCMS: m/z $402.2\left[\mathrm{M}^{+}\right]$, $404.2\left[\mathrm{M}^{+}+2\right]$ and $406.2\left[\mathrm{M}^{+}+4\right]$.

\section{Antimicrobial activity}

Antibacterial activity of the synthesized compounds was tested against five bacterial strains and three fungal strains using agar well diffusion method [28]. Dimethyl sulfoxide was used as solvent control. The bacterial culture was inoculated on nutrient agar and fungal culture was inoculated on potato dextrose agar media $(20 \mathrm{ml})$. The test compounds were dissolved in DMSO to get a concentration of $12.79 \mathrm{M}$ and $100 \mu \mathrm{L}$ of this sample was loaded into the wells of agar plates directly. Plates inoculated with the bacteria were incubated at $37^{\circ} \mathrm{C}$ for $24 \mathrm{~h}$ and the fungal culture was incubated at $25^{\circ} \mathrm{C}$ for $72 \mathrm{~h}$. All determinations were done in triplicates. The Streptomycin $(1.71 \mathrm{M}$ and $0.85 \mathrm{M})$ and Griseofulvin $(3.26 \mathrm{M}$ and $1.6 \mathrm{M})$ were used as standard drugs for antibacterial and antifungal activities respectively.

The minimum inhibitory concentration (MIC) was performed by serial broth-dilution method [29] at different concentrations like 1, $10,25,50$ and $100 \mu \mathrm{g} / \mathrm{mL}$. After the incubation period, the minimum inhibition zone at which the microorganism growth was inhibited was measured in $\mu \mathrm{g} / \mathrm{mL}$.

\section{In silico molecular docking studies}

The compounds synthesized in the present investigation were subjected for molecular docking studies using Auto Dock (version 4.2) with Lamarckian genetic algorithm. The synthesized compounds having $2 \mathrm{D}$ structure were converted to energy minimized 3D structures and were further used for in silico protein-ligand docking. The synthesized compounds were used as ligand. The docking of receptor GlcN-6-P with newly synthesized compounds exhibited well established bonds with one or more amino acids in the receptor active pocket. The active pocket was considered to be the site where glucosamine-6-phosphate complexes with GlcN-6-P of 2VF5. The active pocket consisted of 12 amino acid residues as Ala602, Val399, Ala400, Gly301, Thr302, Ser303, Cys300, Gln348, Ser349, Thr352, Ser347 and Lys603 [30].

The crystal structure of GlcN-6-P synthase (PDB ID 2VF5) from the PDB (http://www.pdb.org/pdb/home/home.do) was selected and edited by removing the heteroatoms and adding C-terminal oxygen [31]. The Graphical User Interface program "AutoDock Tools" was used 
to prepare, run and analyze the docking simulations. Kollman united atom charges, solvation parameters and polar hydrogens were added to the receptor for the preparation of protein in docking simulation. Since ligands are not peptides, Gasteiger charge was assigned and then non-polar hydrogens were merged.

\section{Antioxidant activity}

Free radical scavenging activity by DPPH method: Free radicalscavenging capacities of synthesized compounds were determined according to the reported procedure [32]. The newly synthesized compounds at different concentrations $(25-100 \mu \mathrm{g} / \mathrm{mL})$ were added to each test tube and volume was made up to $4 \mathrm{ml}$ using methanol. To this, $3 \mathrm{ml}$ of $0.004 \% \mathrm{DPPH}$ in methanol was added and the mixtures were incubated at room temperature under dark condition for $30 \mathrm{~min}$. The absorbance was recorded at $517 \mathrm{~nm}$ using UVVisible spectrophotometer (Shimadzu UV-1800, Japan). Butylated hydroxy toluene (BHT), dissolved in distilled water was used as a reference. Control sample was prepared using the same volume without any compound and BHT, 95\% methanol served as blank. Test was performed in triplicate and the results were averaged. Radical scavenging activity was calculated using the formula:

$$
\% \text { of radical scavenging activity }=\left[\left(\mathrm{A}_{\text {control }}-\mathrm{A}_{\text {test }}\right) / \mathrm{A}_{\text {control }}\right] \times 100
$$

Where $A_{\text {control }}$ is the absorbance of the control sample (DPPH solution without test sample) and $\mathrm{A}_{\text {test }}$ is the absorbance of the test sample (DPPH solution+test compound).

Iron chelating ability: The chelating effect was determined according to the literature method [33]. The test solution $(2 \mathrm{ml})$ of different concentrations $(25-100 \mu \mathrm{g} / \mathrm{mL})$ in methanol was added to a solution of $2 \mathrm{mM} \mathrm{FeCl}_{2}(0.05 \mathrm{ml})$, the reaction was initiated by adding
$5 \mathrm{mM}$ ferrozine $(0.2 \mathrm{ml})$ and total volume was adjusted to $5 \mathrm{ml}$ with methanol. Then, the mixture was shaken vigorously and left at room temperature for $10 \mathrm{~min}$. Absorbance of the solution was measured spectrophotometrically at $562 \mathrm{~nm}$. EDTA was used as a standard. The inhibition percentage of ferrozine- $\mathrm{Fe}^{+2}$ complex formations was calculated using the formula:

$$
\text { Metal chelating effect }(\%)=\left[\left(\mathrm{A}_{\text {control }}-\mathrm{A}_{\text {sample }}\right) / \mathrm{A}_{\text {control }}\right] \times 100
$$

Where $A_{\text {control }}$ is the absorbance of control and $A_{\text {sample }}$ is the absorbance of test compounds. Ascorbic acid is used as control. Test was performed in triplicate and the results were averaged.

Reducing power assay: The reducing power of the test samples was evaluated by following the literature method [34]. Various concentrations of test compounds were mixed thoroughly with the mixture of $2.5 \mathrm{ml}$ of $0.2 \mathrm{mM}$ phosphate buffer (pH7.4) and $2.5 \mathrm{ml}$ of potassium ferricyanide. The resulting mixture was incubated at $50^{\circ} \mathrm{C}$ for $20 \mathrm{~min}$, followed by the addition of $2.5 \mathrm{ml}$ of trichloroacetic acid $(10 \% \mathrm{w} / \mathrm{v})$ and the mixture was centrifuged at $3000 \mathrm{rpm}$ for $10 \mathrm{~min}$. The upper layer of the solution was collected and mixed with $2.5 \mathrm{ml}$ distilled water and later with $0.5 \mathrm{ml}$ of ferrous chloride $(0.1 \% \mathrm{w} / \mathrm{v})$. The absorbance was measured at $700 \mathrm{~nm}$ against a blank sample. Increase in the absorbance of the reaction mixture indicated higher reducing power of the test compounds.

\section{Results and Discussion}

\section{Chemistry}

The reaction pathway used for the synthesis of target compounds $(\mathbf{5 a}-\mathbf{k})$ has been shown in Scheme 1. The key intermediates, 1,3-diaryl2-propen-1-ones (3a-k) were synthesized by the reaction of substituted<smiles>[R]c1ccc(C(=O)C=O)cc1</smiles>

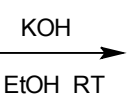

$(2 a-f)$<smiles>[R]c1ccc(/C=C/C(=O)c2ccc([R])cc2)cc1</smiles>

(3a-k)

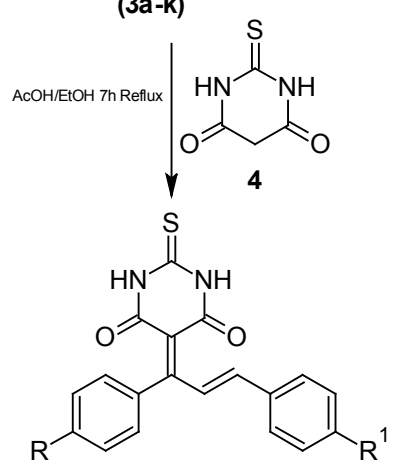

(5a-k)

$\begin{array}{llllll}\mathbf{C o m p} & \mathbf{R} & \mathbf{R}_{\mathbf{1}} & \mathbf{C o m p} & \mathbf{R} & \mathbf{R}_{\mathbf{1}} \\ \mathbf{5 a} & \mathrm{H} & \mathrm{Cl} & \mathbf{5 g} & \mathrm{OCH}_{3} & \mathrm{OH} \\ \mathbf{5 b} & \mathrm{H} & \mathrm{CH}_{3} & \mathbf{5 h} & \mathrm{OCH}_{3} & \mathrm{H} \\ \mathbf{5 c} & \mathrm{H} & \mathrm{OCH}_{3} & \mathbf{5 i} & \mathrm{NO}_{2} & \mathrm{OCH}_{3} \\ \mathbf{5 d} & \mathrm{H} & \mathrm{N}\left(\mathrm{CH}_{3}\right)_{2} & \mathbf{5 j} & \mathrm{NO}_{2} & \mathrm{~N}\left(\mathrm{CH}_{3}\right)_{2} \\ \mathbf{5 e} & \mathrm{OCH}_{3} & \mathrm{Cl} & \mathbf{5 k} & \mathrm{Cl} & \mathrm{Cl} \\ \mathbf{5 f} & \mathrm{OCH}_{3} & \mathrm{CH}_{3} & & & \end{array}$

Scheme 1: Synthesis of chalcone derivatives containing thiobarbitone nucleus (5a-k). 
acetophenones with different aromatic aldehydes according to the reported procedure [35]. The Knoevenagel condensation of 1,3-diaryl2-propen-1-ones (3a-k) with thiobarbituric acid (4) furnished the target compound (5a-k). Initially, 1,3-diaryl-2-propen-1-one undergo protonation by acetic acid. The protonated form of the methanone then facilitates the addition reaction towards a nucleophile. The acetate ion which was formed in the former step can accept a proton from the methylene unit of thiobarbituric acid and generate a carbanion. The electron-rich carbanion attacks on the electron deficient carbonyl carbon of 1,3-diaryl-2-propen-1-one to form an adduct which upon dehydration furnished the target compounds. The proposed mechanism is given in Figure 1.

The structures of synthesized compounds were confirmed by IR, NMR and Mass spectral data. The IR spectrum of compound 5a showed sharp absorption bands at $1657 \mathrm{~cm}^{-1}$ and $1653 \mathrm{~cm}^{-1}$ corresponding to carbonyl group $(\mathrm{C}=\mathrm{O})$. The absorption band in the region $3300-3313 \mathrm{~cm}^{-1}$ corresponds to $(\mathrm{NH})$ stretching vibration and the band at $1350 \mathrm{~cm}^{-1}$ corresponds to $(\mathrm{C}=\mathrm{S})$ stretching vibration. The ${ }^{1} \mathrm{H}$ NMR spectrum of compound $\mathbf{5 a}$ displayed two doublets at $\delta 7.10$ and $5.72 \mathrm{ppm}$ due to two vinyl protons, the multiplet between $\delta 8.30$ $7.53 \mathrm{ppm}$ correspond to aromatic protons and a singlet at $\delta 8.95 \mathrm{ppm}$ is due to two NH protons. Further, ${ }^{13} \mathrm{CNMR}$ spectrum of compound 5a confirmed the proposed structure by appearance of signal at $\delta$ $178.1 \mathrm{ppm}$ due to the $\mathrm{C}=\mathrm{S}$ carbon and another signal at $\delta 167 \mathrm{ppm}$ correspond to $\mathrm{C}=\mathrm{O}$ carbon of thiobarbituric acid ring. Another signal at $\delta 133.50 \mathrm{ppm}$ attributed to $\mathrm{C}-\mathrm{Cl}$ carbon and rest of carbon atoms displayed the signals at respective $\delta$ values pertaining to the structure. The mass spectrum showed molecular ion peak $\mathrm{M}^{+}$at $\mathrm{m} / \mathrm{z}$ at 368.20 which corresponds to molecular weight of the compound $\mathbf{5 a}$ and isotopic peak at $\mathrm{m} / \mathrm{z} 370.2\left[\mathrm{M}^{+}+2\right]$. The physical and analytical data of synthesized compounds (5a-k) have been given in Table 1 .

\section{Biological activity}

In vitro antibacterial and antifungal activity: Though, we have many synthetic drugs in the market, the bacterial mutations are making them resistance. In view of this, the compounds synthesized in the present investigation (5a-k) were evaluated for their antimicrobial activity as primary screening at two different concentrations and the results have been displayed in Tables 2 and 3. The antimicrobial activity was carried out against five bacterial strains Staphylococcus aureus (MTCC 3160), Bacillus subtilis (MTCC 1134), Escherichia coli (MTCC 1559), Salmonella tyhphi (MTCC 1160), Pseudomonas aeruginosa (MTCC 1034) and three fungi Candida albicans (MTCC 1637), Aspergillus niger (MTCC 4325) and Alternaria alternata (MTCC 3793). All these microorganisms were procured from IMTECH, Chandigarh, India.

The investigation of antimicrobial screening revealed that, test compounds showed varying degree of activity against all the tested microorganisms. Further, the compounds which showed good activity in primary screening were assessed by minimum inhibitory concentration (MIC) at different concentrations to quantify the antimicrobial potency of the compounds. The results of MIC values of antimicrobial activity have been given in Table 4.

From the structure-antimicrobial activity connection of the synthesized compounds, it revealed that, to assess the SAR studies, the effect of structural changes in the target compounds and the role of substituents in improving anti-microbial activities have been reported in the literature [36-41]. A close investigation of the MIC values indicates that all the compounds exhibited a varied degree of MIC $(27.72-198.10 \mu \mathrm{g} / \mathrm{mL})$ of antibacterial activity against the tested bacterial strains. The compounds $\mathbf{5 a}, \mathbf{5 e}$ and $\mathbf{5 k}$ having $\mathrm{Cl}$ substituents on para position of phenyl ring were found to exhibit good antibacterial activity against Staphylococcus aureus and bacillus subtilis with MIC value $27.72-37.42 \mu \mathrm{g} / \mathrm{mL}$. Compounds $\mathbf{5 i}$ and $\mathbf{5 j}$ showed very good activity against Pseudomonas aeruginosa with MIC value $28.11 \mu \mathrm{g} / \mathrm{mL}$ and $29.86 \mu \mathrm{g} / \mathrm{mL}$ respectively; Compound $\mathbf{5 c}$ is inactive against the Staphylococcus aureus and remaining compounds showed considerable activity against all tested strains.

The MIC of antifungal activity of title compounds indicated that, the compound 5e was found to exhibit good activity against all the tested fungal strains with MIC value 23.50- $28.00 \mu \mathrm{g} / \mathrm{mL}$. Compounds $5 \mathbf{i}$ and $5 \mathbf{j}$ showed moderate activity against the tested fungal microorganisms Aspergillus niger and Alternaria alternata with MIC value $22.66-36.49 \mu \mathrm{g} / \mathrm{mL}$.

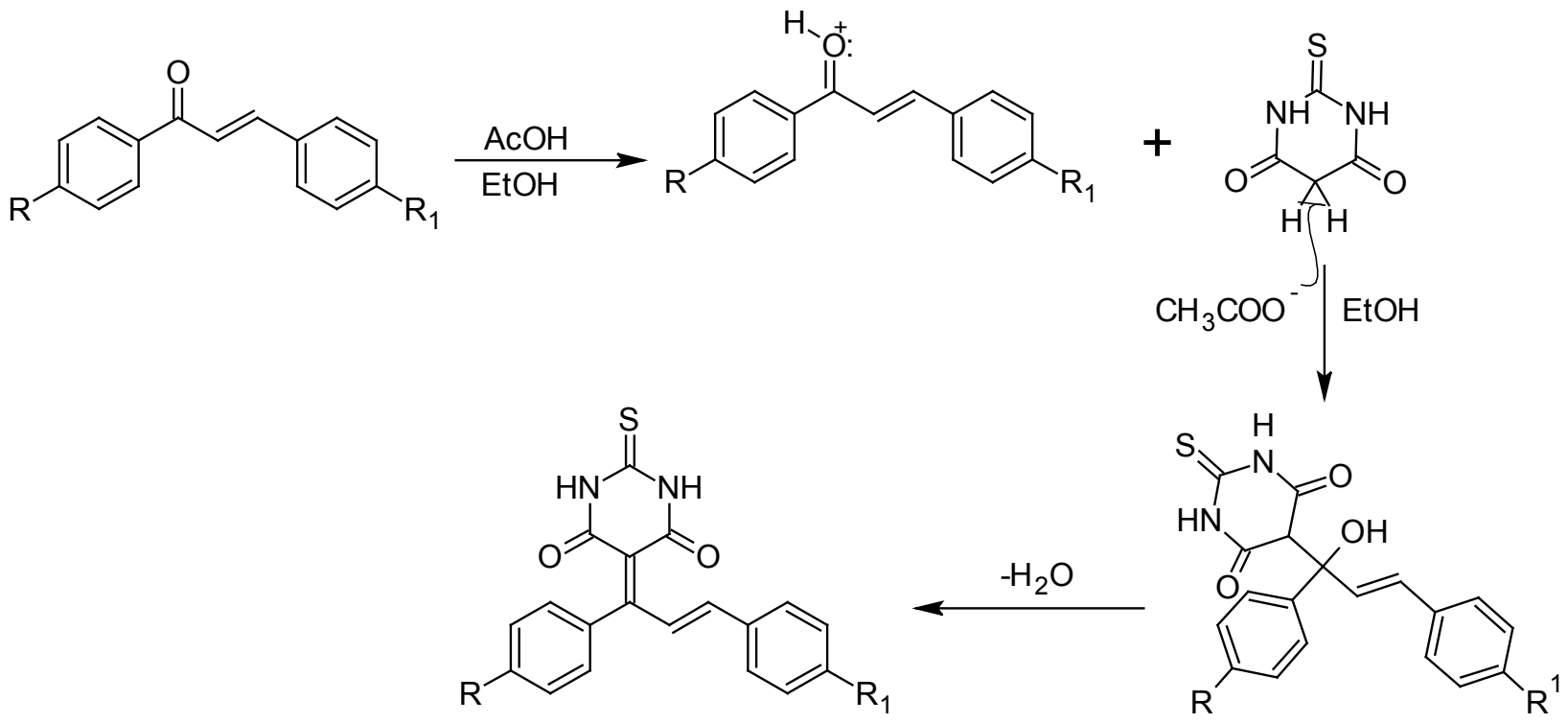

Figure 1: Proposed mechanism for formation of compounds (5a-k). 


\begin{tabular}{|c|c|c|c|c|}
\hline Compd & $\mathbf{R}$ & $\mathbf{R}_{1}$ & Yield (\%) & Mol. Wt. \\
\hline $5 a$ & $\mathrm{H}$ & $\mathrm{Cl}$ & 79 & 368.83 \\
\hline $5 b$ & $\mathrm{H}$ & $\mathrm{CH}_{3}$ & 90 & 348.41 \\
\hline $5 c$ & $\mathrm{H}$ & $\mathrm{OCH}_{3}$ & 86 & 364.41 \\
\hline $5 d$ & $\mathrm{H}$ & $\mathrm{N}\left(\mathrm{CH}_{3}\right)_{2}$ & 83 & 377.45 \\
\hline $5 e$ & $\mathrm{OCH}_{3}$ & $\mathrm{Cl}$ & 85 & 398.86 \\
\hline $5 f$ & $\mathrm{OCH}_{3}$ & $\mathrm{CH}_{3}$ & 76 & 378.44 \\
\hline $5 g$ & $\mathrm{OCH}_{3}$ & $\mathrm{OH}$ & 91 & 380.45 \\
\hline $5 \mathrm{~h}$ & $\mathrm{OCH}_{3}$ & $\mathrm{H}$ & 75 & 364.41 \\
\hline $5 i$ & $\mathrm{NO}_{2}$ & $\mathrm{OCH}_{3}$ & 83 & 409.41 \\
\hline $5 j$ & $\mathrm{NO}_{2}$ & $\mathrm{~N}\left(\mathrm{CH}_{3}\right)_{2}$ & 79 & 422.45 \\
\hline $5 k$ & $\mathrm{Cl}$ & $\mathrm{Cl}$ & 81 & 403.20 \\
\hline
\end{tabular}

Table 1: Characterization data of synthesized compounds (5a-k).

\begin{tabular}{|c|c|c|c|c|c|c|}
\hline \multirow{2}{*}{ Comp. No } & \multirow{2}{*}{ Conc. in $(\mathrm{mg} / \mathrm{mL})$} & \multicolumn{5}{|c|}{ Zone of inhibition in $\mathrm{mm}$ (mean \pm S.D.) } \\
\hline & & S. $a \pm S . D^{*}$ & B. $s \pm S . D^{*}$ & E. $c \pm S . D^{*}$ & S. $t \pm S . D^{*}$ & P. $a \pm$ S.D* \\
\hline \multirow{2}{*}{$5 a$} & 0.5 & $9 \pm 0.13$ & $6 \pm 0.17$ & $6 \pm 0.16$ & 00 & 00 \\
\hline & 1.0 & $20 \pm 0.12$ & $10 \pm 0.15$ & $9 \pm 0.12$ & $8 \pm 0.14$ & $9 \pm 0.133$ \\
\hline \multirow{2}{*}{$5 b$} & 0.5 & $8 \pm 0.14$ & $08 \pm 0.1$ & $7 \pm 0.17$ & 00 & $6 \pm 0.17$ \\
\hline & 1.0 & $17 \pm 0.18$ & $10 \pm 0.2$ & $9 \pm 0.16$ & $8 \pm 0.14$ & $9 \pm 0.18$ \\
\hline \multirow{2}{*}{$5 c$} & 0.5 & $11 \pm 0.19$ & $12 \pm 0.18$ & $6 \pm 0.12$ & $6 \pm 0.15$ & $7 \pm 0.17$ \\
\hline & 1.0 & $19 \pm 0.15$ & $21 \pm 0.15$ & $14 \pm 0.16$ & $12 \pm 0.14$ & $13 \pm 0.13$ \\
\hline \multirow{2}{*}{$5 d$} & 0.5 & $6 \pm 0.14$ & $6 \pm 0.12$ & $6 \pm 0.18$ & $6 \pm 0.13$ & 00 \\
\hline & 1.0 & $13 \pm 0.16$ & $10 \pm 0.14$ & $8 \pm 0.17$ & $8 \pm 0.14$ & $9 \pm 0.14$ \\
\hline \multirow{2}{*}{$5 e$} & 0.5 & $7 \pm 0.19$ & $7 \pm 0.17$ & $7 \pm 0.17$ & $8 \pm 0.17$ & $7 \pm 0.17$ \\
\hline & 1.0 & $15 \pm 0.12$ & $12 \pm 0.16$ & $14 \pm 0.16$ & $13 \pm 0.16$ & $13 \pm 0.16$ \\
\hline \multirow{2}{*}{$5 f$} & 0.5 & $6 \pm 0.14$ & $5 \pm 0.18$ & $8 \pm 0.15$ & 00 & $6 \pm 0.17$ \\
\hline & 1.0 & $13 \pm 0.16$ & $11 \pm 0.15$ & $13 \pm 0.18$ & $6 \pm 0.17$ & $9 \pm 0.12$ \\
\hline \multirow{2}{*}{$5 \mathrm{~g}$} & 0.5 & $6 \pm 0.14$ & $7 \pm 0.17$ & $6 \pm 0.17$ & $6 \pm 0.16$ & 00 \\
\hline & 1.0 & $10 \pm 0.18$ & $15 \pm 0.18$ & $10 \pm 0.15$ & $9 \pm 0.17$ & $6 \pm 0.14$ \\
\hline \multirow{2}{*}{$5 \mathrm{~h}$} & 0.5 & $7 \pm 0.13$ & $6 \pm 0.12$ & $6 \pm 0.14$ & 00 & 00 \\
\hline & 1.0 & $14 \pm 0.17$ & $13 \pm 0.17$ & $9 \pm 0.13$ & $7 \pm 0.19$ & 00 \\
\hline \multirow{2}{*}{$5 i$} & 0.5 & $11 \pm .015$ & $10 \pm 0.18$ & $9 \pm 0.17$ & $7 \pm 0.12$ & $6 \pm 0.12$ \\
\hline & 1.0 & $20 \pm 0.15$ & $18 \pm 0.16$ & $16 \pm 0.15$ & $11 \pm 0.14$ & $12 \pm 0.16$ \\
\hline \multirow{2}{*}{$5 \mathrm{j}$} & 0.5 & $12 \pm 0.18$ & $10 \pm 0.15$ & $9 \pm 0.16$ & $9 \pm 0.16$ & $8 \pm 0.15$ \\
\hline & 1.0 & $21 \pm 0.16$ & $18 \pm 0.13$ & $16 \pm 0.16$ & $13 \pm 0.15$ & $13 \pm 0.17$ \\
\hline \multirow{2}{*}{$5 \mathrm{k}$} & 0.5 & $13 \pm 0.2$ & $11 \pm 0.1$ & $09 \pm 0.2$ & $11 \pm 0.3$ & $09 \pm 0.2$ \\
\hline & 1.0 & $21 \pm 0.3$ & $18 \pm 0.2$ & $16 \pm 0.1$ & $14 \pm 0.1$ & $14 \pm 0.3$ \\
\hline \multirow{2}{*}{$\begin{array}{c}10 \% \\
\text { DMSO }\end{array}$} & & & & & & \\
\hline & - & - & - & - & - & - \\
\hline Streptomycin & & $24 \pm 0.16$ & $21 \pm 0.12$ & $18 \pm 0.13$ & $16 \pm 0.17$ & $15 \pm 0.18$ \\
\hline
\end{tabular}

Each value is the mean of three replicate determinations \pm standard deviation; $S$. a - Staphylococcus aureus; B. $s$ Bacillus subtilis; E. c - Escherichia coli; $S$. $t$ - Salmonella tyhphi; P. a - Pseudomonas aeruginosa 


\begin{tabular}{|c|c|c|c|c|}
\hline \multirow{2}{*}{ Comp. No } & \multirow{2}{*}{ Conc. in (mg/mL) } & \multicolumn{3}{|c|}{ Zone of inhibition in $\mathrm{mm}$ (mean \pm S.D.) } \\
\hline & & C. $a \pm S . D^{*}$ & A. $n \pm S . \mathrm{D}^{*}$ & A. $a \pm S . D^{*}$ \\
\hline \multirow{2}{*}{$5 a$} & 0.5 & $6 \pm 0.13$ & $6 \pm 0.15$ & 00 \\
\hline & 1.0 & $10 \pm 0.14$ & $12 \pm 0.13$ & $6 \pm 0.18$ \\
\hline \multirow{2}{*}{$5 b$} & 0.5 & $7 \pm 0.12$ & $8 \pm 0.14$ & $6 \pm 0.17$ \\
\hline & 1.0 & $10 \pm 0.17$ & $11 \pm 0.12$ & $8 \pm 0.12$ \\
\hline \multirow{2}{*}{$5 \mathrm{c}$} & 0.5 & $8 \pm 0.15$ & $7 \pm 0.17$ & $7 \pm 0.18$ \\
\hline & 1.0 & $10 \pm 0.15$ & $11 \pm 0.16$ & $12 \pm 0.15$ \\
\hline \multirow{2}{*}{$5 d$} & 0.5 & 00 & 00 & $6 \pm 0.17$ \\
\hline & 1.0 & $8 \pm 0.18$ & 00 & 00 \\
\hline \multirow{2}{*}{$5 e$} & 0.5 & $7 \pm 0.16$ & $8 \pm 0.12$ & $6 \pm 0.17$ \\
\hline & 1.0 & $12 \pm 0.17$ & $16 \pm 0.15$ & $10 \pm 0.13$ \\
\hline \multirow{2}{*}{$5 f$} & 0.5 & 00 & $6 \pm 0.18$ & $6 \pm 0.17$ \\
\hline & 1.0 & $8 \pm 0.12$ & $8 \pm 0.12$ & $9 \pm 0.15$ \\
\hline \multirow{2}{*}{$5 g$} & 0.5 & 00 & $6 \pm 0.18$ & $6 \pm 0.17$ \\
\hline & 1.0 & $8 \pm 0.12$ & $8 \pm 0.12$ & $9 \pm 0.15$ \\
\hline \multirow{2}{*}{$5 \mathrm{~h}$} & 0.5 & 00 & 00 & 00 \\
\hline & 1.0 & $9 \pm 0.15$ & 00 & 00 \\
\hline \multirow{2}{*}{$5 i$} & 0.5 & $6 \pm 0.13$ & $7 \pm 0.14$ & $7 \pm 0.19$ \\
\hline & 1.0 & $11 \pm 0.15$ & $15 \pm 0.15$ & $12 \pm 0.15$ \\
\hline \multirow{2}{*}{$5 j$} & 0.5 & $6 \pm 0.12$ & $7 \pm 0.14$ & $6 \pm 0.15$ \\
\hline & 1.0 & $11 \pm 0.16$ & $10 \pm 0.14$ & $11 \pm 0.17$ \\
\hline \multirow{2}{*}{$5 \mathrm{k}$} & 0.5 & $7 \pm 0.18$ & $8 \pm 0.15$ & $7 \pm 0.17$ \\
\hline & 1.0 & $13 \pm 0.15$ & $17 \pm 0.15$ & $13 \pm 0.16$ \\
\hline $10 \%$ DMSO & _ & _ & _ & _ \\
\hline Griseofulvin & & $14 \pm 0.16$ & $19 \pm 0.13$ & $16 \pm 0.15$ \\
\hline & & & & \\
\hline
\end{tabular}

Each value is the mean of three replicate determinations \pm standard deviation; $C$. a - Candida albicans; A. $n$ - Aspergillus niger; A. a - Alternaria alternata Table 3: Antifungal activity data of synthesized compounds (5a-k).

\begin{tabular}{|c|c|c|c|c|c|c|c|c|}
\hline \multirow{2}{*}{ Comp. No } & \multirow[b]{2}{*}{ S. $a$} & \multicolumn{7}{|c|}{ Minimum inhibitory concentration (MIC $\mu \mathrm{g} / \mathrm{mL}$ ) } \\
\hline & & B. $s$ & E. $c$ & S. $t$ & P. $a$ & C. $a$ & A. $n$ & A. $a$ \\
\hline $5 a$ & 32.14 & 31.08 & -- & 31.11 & 27.01 & -- & 64.49 & 42.61 \\
\hline $5 c$ & -- & 198.10 & 182.98 & 179.18 & 159.34 & 68.17 & -- & 48.25 \\
\hline $5 e$ & 28.76 & 27.72 & 29.84 & 32.54 & 30.05 & 28.00 & 30.09 & 23.50 \\
\hline $5 i$ & 31.02 & 32.53 & 31.16 & 30.26 & 29.86 & 35.51 & 35.51 & 25.50 \\
\hline $5 j$ & 32.34 & 32.68 & 33.78 & 43.21 & 28.11 & -- & 36.49 & 22.66 \\
\hline $5 \mathrm{k}$ & 35.59 & 35.08 & 37.42 & 31.30 & 34.31 & 41.10 & 42.22 & 23.96 \\
\hline Streptomycin & 24.95 & 24.95 & 26.67 & 26.24 & 26.24 & -- & -- & -- \\
\hline Griseofulvin & -- & -- & -- & -- & -- & 24.84 & 24.84 & 20.42 \\
\hline
\end{tabular}

S. a - Staphylococcus aureus; B. s - Bacillus subtilis; E. c - Escherichia coli; S. $t$ - Salmonella tyhphi; P. a - Pseudomonas aeruginosa; C. a - Candida albicans; A. $n$ Aspergillus niger, A. a - Alternaria alternata

Table 4: Minimum inhibitory concentration (MIC) of synthesized compounds (5a-k).

In silico molecular docking studies: Glucosamine-6-phosphate synthase (L-glutamine: D-fructose-6-phosphate amino transferase) catalyze the first step in hexamine biosynthesis, converting D-fructose6-phosphate (Fru-6-P) into D-glucosamine 6-phosphate (GlcN-6-P) using glutamine as the ammonia source. The amino sugars are the significant building blocks of polysaccharides found in the cell wall of most human pathogenic microorganisms. Therefore not surprising that a number of GlcN-6-P synthase inhibitors of natural or synthetic origin display bactericidal or fungicidal properties [42]. In correlation to in vitro antimicrobial activity, it thought worthwhile to carryout in silico studies of target molecules $\mathbf{5 a}, \mathbf{5 e}$ and $\mathbf{5 k}$ to predict the binding affinity and orientation at the active site of the receptor.

Automated docking was used to assess the orientation of inhibitors bound in the active pockets of GlcN-6-P synthase. The molecular docking of molecules $5 \mathbf{a}, \mathbf{5 e}$ and $\mathbf{5 k}$ with GlcN-6-P synthase revealed that all tested compounds have shown the bonding with one or the other amino acids in the active pockets as shown in Figure 2.

Among the three molecules $\mathbf{5 a}, \mathbf{5 e}$ and $\mathbf{5 k}$, the docking of GlcN6-P synthase with compounds $5 \mathbf{a}$ and $\mathbf{5 e}$ were found with least binding energy $\left(-4.41 \mathrm{~kJ} \mathrm{~mol}^{-1}\right)$. Compound $5 \mathbf{a}$ establishes two hydrogen bonds between thiobarbitone $\mathrm{NH}$ with ser 347 and thiobarbitone oxygen with ser 349 amino acids in the active site of the target protein with minimum bond length (2.003 and 2.143 $\AA$ ). Compound 5e establishes two hydrogen bonds between $\mathrm{NH}$ with gln 348 and thiobarbitone oxygen with ser 349 amino acids in the active site of the target protein with minimum bond length (2.246 and $2.143 \AA$ ). In in vitro studies too, 


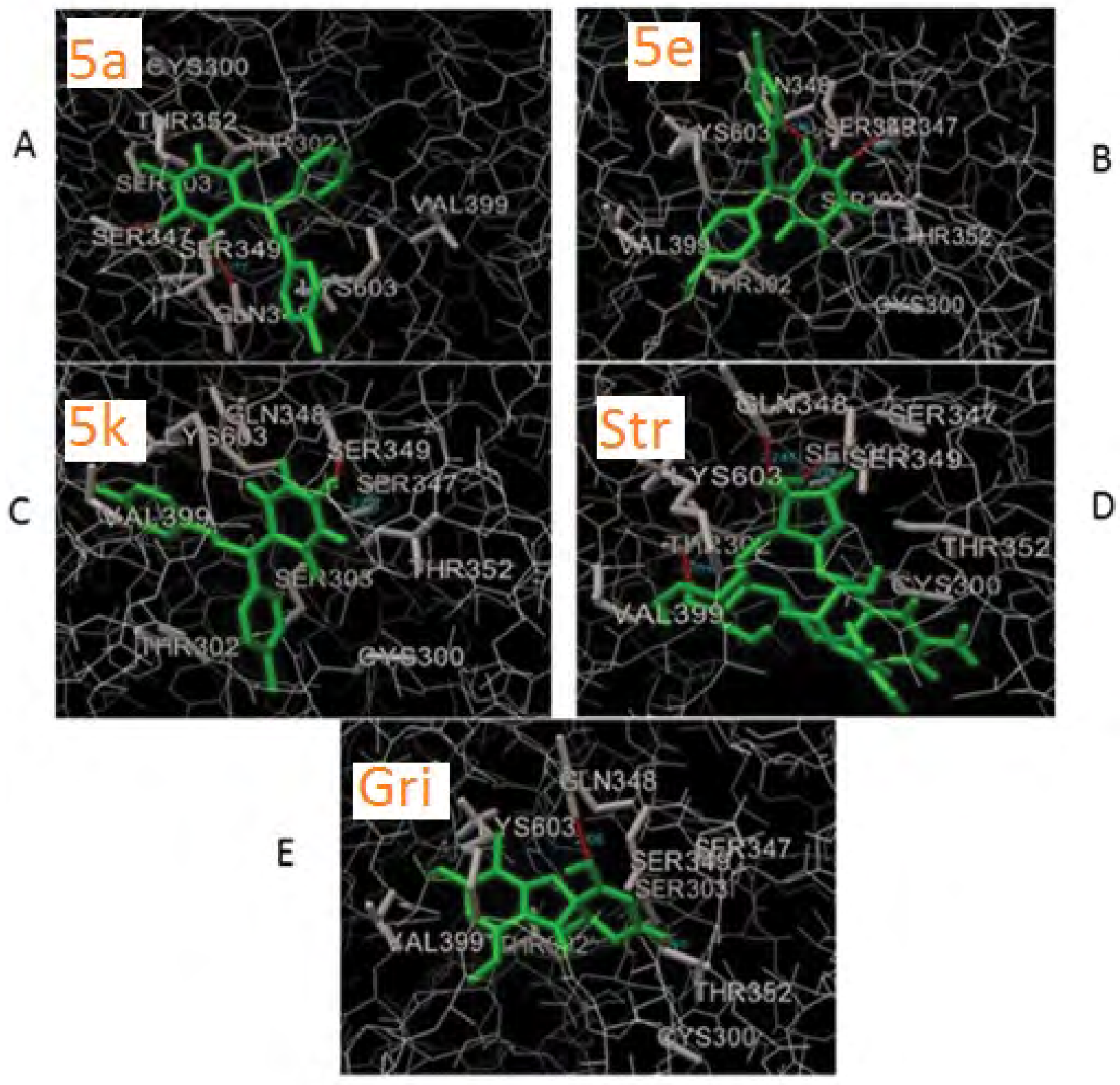

Figure 2: Interaction of ligand molecules $5 \mathrm{a}, 5 \mathrm{e}, 5 \mathrm{k}$, Str and Gri with GlcN-6-P. A: interaction of 5a with GlcN-6-P; B: interaction of 5e with GlcN-6-P; C: interaction of $5 \mathrm{k}$ with GIcN-6-P; D: Interaction of Streptomycin (Str) with GIcN-6-P; E: interaction of Griseofulvin (Gri) with GIcN-6-P.

compounds $\mathbf{5} \mathbf{a}$ and $\mathbf{5 e}$ have emerged as an active antimicrobial agent against the tested organisms. Molecular docking results of synthesized compounds have been given in Table 5.

Free radical scavenging activity by DPPH method: All the synthesized compounds were screened for their free radical scavenging activity by DPPH method. The Freshly prepared solution exhibits a deep blue color with the absorption maximum at $517 \mathrm{~mm}$. This deep blue color generally fades when antioxidant is present in the solution. All compounds have exhibited varied free radial scavenging capacity by comparison with the standard Butylated hydroxy toluene (BHT). The variation exhibited in DPPH scavenging activity could be attributed to the effect of different substituents. The compound substituted with phenolic hydroxy group has the high potential for scavenging radicals [43]. Among the tested compounds, compounds $\mathbf{5} \mathbf{c}$ and $\mathbf{5 f}$ displayed potent $\mathrm{DPPH}$ free radical scavenging activity with least $\mathrm{IC}_{50}$ value $(55.58-58.68 \mu \mathrm{g} / \mathrm{mL})$. Compounds $\mathbf{5 b}$ and $\mathbf{5 i}$ displayed good activity with the $\mathrm{IC}_{50}$ value 61.88 and $65.78 \mu \mathrm{g} / \mathrm{mL}$ respectively.

Iron chelating ability: The iron chelating study measures the ability of antioxidants to compete with Ferrozine in chelating ferrous ion [44]. The $\mathrm{Fe}^{+2}$ chelating capacities varied significantly among different compounds. From the activity results it revealed that, among the tested compounds, compounds $\mathbf{5 b}, \mathbf{5} \mathbf{f}$ and $\mathbf{5 i}$ showed very good chelating ability with $\mathrm{IC}_{50}$ value 62.81-69.06 $\mu \mathrm{g} / \mathrm{mL}$. Further, it was observed that the compound $\mathbf{5 c}$ substituted with methoxy group at C-4 of aromatic 


\begin{tabular}{|c|c|c|c|c|c|c|c|}
\hline Comp. No & $\begin{array}{l}\text { Binding Energy } \\
\left(\mathrm{kJ} \mathrm{mol}^{-1}\right)\end{array}$ & $\begin{array}{c}\text { Inhibition } \\
\text { Constant } \\
(\mu \mathrm{M})\end{array}$ & RMSd & $\begin{array}{l}\text { Ligand } \\
\text { efficiency }\end{array}$ & $\begin{array}{l}\text { No of } \\
\text { hydrogen } \\
\text { bonds }\end{array}$ & Bonding residues & $\begin{array}{l}\text { Bond length } \\
\text { (A) }\end{array}$ \\
\hline $5 a$ & -4.41 & 583.09 & 0.0 & -0.18 & 2 & $\begin{array}{l}\text { 2VF5: GLN348: HE22 : Ligands / 4a:: : H } \\
\text { 2VF5: SER347: HG1: Ligands/ 4a:: : O }\end{array}$ & $\begin{array}{l}2.003 \\
2.143\end{array}$ \\
\hline $5 e$ & -4.41 & 589.5 & 0.0 & -0.16 & 2 & $\begin{array}{l}\text { 2VF5: GLN348: HE22: Ligands / 4e:: : H } \\
\text { 2VF5:SER349: HG: Ligands/ 4c:: : O }\end{array}$ & $\begin{array}{l}2.246 \\
2.163\end{array}$ \\
\hline $5 k$ & -4.52 & 487.83 & 0.0 & -0.17 & 1 & 2VF5:SER349: HG: Ligands/ 4e:: : O & 2.007 \\
\hline Streptomycin & -6.72 & -181.49 & 0.0 & -0.17 & 2 & $\begin{array}{c}\text { 2VF5:SER349: HG: Ligands/ Streptomycin:: } \\
\text { : O } \\
\begin{aligned} \text { 2VF5:THR352:OG1: Ligands/ Streptomycin:: } \\
: H\end{aligned}\end{array}$ & $\begin{array}{l}1.922 \\
1.894\end{array}$ \\
\hline Griseofulvin & -4.84 & -282.81 & 0.0 & -0.12 & 2 & $\begin{array}{c}\text { 2VF5:GLN348: HE22: Ligands/ Griseofulvin:: } \\
\text { : O } \\
\text { 2VF5:THR352:OG1: Ligands/ Griseofulvin } \\
:: \mathrm{H}\end{array}$ & $\begin{array}{l}2.106 \\
2.346\end{array}$ \\
\hline
\end{tabular}

Table 5: Molecular docking results of synthesized compounds (5a-k) with Glucosamine-6-Phosphate Synthase.

\begin{tabular}{|c|c|c|c|}
\hline Test Compd & $\begin{array}{l}\text { DPPH assay } \\
\text { (IC } 50 \mu \mathrm{g} / \mathrm{mL} \text { ) }\end{array}$ & $\begin{array}{l}\mathrm{Fe}^{2+} \text { ion chelating } \\
\quad(\text { IC } 50 \mu \mathrm{g} / \mathrm{mL})\end{array}$ & $\begin{array}{l}\text { Total reductive capability } \\
\text { (IC } 50 \mu \mathrm{g} / \mathrm{mL} \text { ) }\end{array}$ \\
\hline $5 a$ & $85.03 \pm 0.21$ & $88.62 \pm 0.14$ & $91.25 \pm 0.12$ \\
\hline $5 b$ & $61.88 \pm 0.12$ & $67.2 \pm 0.18$ & $64.43 \pm 0.14$ \\
\hline $5 c$ & $55.58 \pm 0.31$ & $58.41 \pm 0.21$ & $63.13 \pm 0.25$ \\
\hline $5 d$ & $168.91 \pm 0.43$ & $176.05 \pm 0.41$ & $204.91 \pm 0.38$ \\
\hline $5 e$ & $75.76 \pm 0.15$ & $81.69 \pm 0.15$ & $92.59 \pm 0.31$ \\
\hline $5 f$ & $58.68 \pm 0.18$ & $62.81 \pm 0.18$ & $72.25 \pm 0.12$ \\
\hline $5 g$ & $94.41 \pm 0.24$ & $96.89 \pm 0.21$ & $91.24 \pm 0.21$ \\
\hline $5 \mathrm{~h}$ & $134.41 \pm 0.18$ & $121.36 \pm 0.13$ & $181.16 \pm 0.18$ \\
\hline $5 i$ & $65.78 \pm 0.21$ & $69.06 \pm 0.21$ & $62.18 \pm 0.12$ \\
\hline $5 j$ & $121.36 \pm 0.13$ & $128.87 \pm 0.12$ & $176.05 \pm 0.27$ \\
\hline $5 k$ & $87.41 \pm 0.24$ & $79.89 \pm 0.21$ & $81.24 \pm 0.21$ \\
\hline Std $\operatorname{tab}^{a, b}$ & $48.63 \pm 0.18$ & $47.17 \pm 0.13$ & $52.3 \pm 0.12$ \\
\hline
\end{tabular}

Each value is expressed as mean \pm SD of three replicates; Std $^{a}$ BHT used as standard for DPPH radical scavenging activity; Std $^{\mathrm{b}}$ EDTA is used as a standard for Fe ${ }^{2+}$ ion chelating activity; $\mathrm{Std}^{c} \mathrm{BHA}$ used as standard for total reductive capability

Table 6: $I_{50}$ value of DPPH radical scavenging, Ferrous ion chelating and total reductive capability activity of test compounds (5a-k).

ring displayed excellent activity with minimum $\mathrm{IC}_{50}$ value $58.41 \mu \mathrm{g} / \mathrm{mL}$. The other compounds showed moderate to good activity.

Total reductive capability: The reduction of $\mathrm{Fe}^{3+}$ to $\mathrm{Fe}^{2+}$ is often used as an indicator for electron donating activity, which is an important mechanism of phenolic antioxidant action. In the reducing power assay, the presence of antioxidant in the synthesized compounds would result in the reduction of $\mathrm{Fe}^{+3}$ to $\mathrm{Fe}^{+2}$ by donating electron(s). The amount of $\mathrm{Fe}^{+2}$ complexes was then monitored by measuring the formation of Perl's Prussian blue at $700 \mathrm{~nm}$. Absorbance at 700 $\mathrm{nm}$ indicates an increase in reducing ability [45]. It was found that the reducing power of all the synthesized compounds increased with the increase in their concentrations. The best reducing power was presented by the compounds $\mathbf{5} \mathbf{c}$ and $\mathbf{5 i}$ with $\mathrm{IC}_{50}$ value $62.18-63.13 \mu \mathrm{g} /$ $\mathrm{mL}$. $\mathrm{IC}_{50}$ values of DPPH radical scavenging and ferrous ion chelating activity of test compounds is given in Table 6.

\section{Conclusion}

We synthesized novel series of chalcone derivatives containing thiobarbiturate moiety and screened for antimicrobial and antioxidant activity. From the antimicrobial study results it revealed that, compounds $\mathbf{5 a}, \mathbf{5 e}$ and $\mathbf{5 k}$ were most effective against all the tested pathogens compared with the other tested compounds. In case of antioxidant screening, compounds containing hydroxyl groups showed very good DPPH radical scavenging activity.

\section{Acknowledgements}

The authors are thankful to the Chairman, Department of Industrial Chemistry,
Kuvempu University, Shankaraghatta, Karnataka, India for providing the laboratory facilities and IISc, Bangalore, Karnataka for providing spectral data.

\section{References}

1. Aly HM, Kamal MM (2012) Efficient one-pot preparation of novel fused chromeno[2,3-d]pyrimidine and pyrano[2,3-d]pyrimidine derivatives. Eur J Med Chem 47: 18-23.

2. Francesca SL (2011) Anti-microbial properties of scutellaria baicalensis and coptis chinensis, two traditional Chinese medicines. Biosci Horizons 1: 119-127.

3. Mathew B, Suresh J, Vinod D (2012) Antitumor activity of 5-[(2E)-1(1H-benzimidazol-2-yl)-3-substituted-phenylprop-2-en-1-ylidene]pyrimidine$2,4,6(1 \mathrm{H}, 3 \mathrm{H}, 5 \mathrm{H})$-triones against Dalton's ascetic lymphoma in mice. Med Chem Res 22: 3911-3917.

4. Grange JM, Zumla A (2002) The global emergency of tuberculosis: what is the cause? J R Soc Promot Health 122: 78-81.

5. Güzeldemirci NU, Küçükbasmaci O (2010) Synthesis and antimicrobial activity evaluation of new 1,2,4-triazoles and 1,3,4-thiadiazoles bearing imidazo[2,1-b] thiazole moiety. Eur J Med Chem 45: 63-68.

6. Kim SH, Pudzianowski AT, Leavitt KJ, Barbosa J, McDonnell PA, et al. (2005) Structure-based design of potent and selective inhibitors of collagenase-3 (MMP-13). Bioorg Med Chem Lett 15: 1101-1106.

7. Suzuki H, Kneller MB, Rock DA, Jones JP, Trager WF, et al. (2004) Activesite characteristics of CYP2C19 and CYP2C9 probed with hydantoin and barbiturate inhibitors. Arch Biochem Biophys 429: 1-15.

8. Haldar MK, Scott MD, Sule N, Srivastava DK, Mallik S (2008) Synthesis of barbiturate-based methionine aminopeptidase- 1 inhibitors. Bioorg Med Chem Lett 18: 2373-2376.

9. Rajanarendar E, Govardhan RK, Krishna SR, Shireesha B, Reddy YN, et al. (2013) Design, synthesis, antimicrobial, anti-inflammatory, and analgesic 
activity of novel dihydrobenzofuro [3,2-e]isoxazolo [4,5-b] azepin-5(5aH)-ones. Med Chem Res 22: 6143-6153.

10. Saberi MR, Vinh TK, Yee WS, Griffiths BJN, Evans PJ, et al. (2006) Potent CYP19 (aromatase) 1-[(benzofuran-2-yl)(phenyl methyl)pyridine, imidazole, and triazole inhibitors: synthesis and biological evaluation. J Med Chem 49: 1016-1022.

11. Bigler L, Spirli C, Fiorotto R, Pettenazzo A, Duner E, et al. (2007) Synthesis and cytotoxicity properties of amiodarone analogues. Eur J Med Chem 42: 861-867.

12. Desai NC, Rajpara KM, Joshi VV, Vaghani HV, Satodiya HM (2013) Synthesis of promising antimicrobial Agents: a novel series of $\mathrm{N}$-(4-(2,6-dichloroquinolin3-yl)-6-(aryl)pyrimidin-2-yl)-2- mrpholinoacetamides. Med Chem Res 22: 1172 1183.

13. Archana, Srivastava VK, Ashok K (2004) Synthesis of some newer derivatives of substituted quinazolinonyl-2-oxo/thiobarbituric acid as potent anticonvulsant agents. Bio Org Med Chem 12: 1257-1264.

14. Hamzeh K, Maryam G (2014) Phthalimide-N-sulfonic acid: a new and efficient organ catalyst for the biginelli reaction under solvent-free conditions. Res Chem Intermed.

15. Nowakowska Z (2007) A review of anti-infective and anti-inflammatory chalcones. Eur J Med Chem 42: 125-137.

16. Li R, Kenyon GL, Cohen FE, Chen X, Gong B, et al. (1995) In vitro antimalarial activity of chalcones and their derivatives. J Med Chem 38: 5031-5037.

17. Awasthi SK, Mishra N, Dixit SK, Singh A, Yadav M, et al. (2009) Antifilarial activity of 1,3-diarylpropen-1-one: effect on glutathione-S-transferase, a phase II detoxification enzyme. Am J Trop Med Hyg 80: 764-768.

18. Ghosh S, Blumenthal HJ, Davidson E, Roseman S (1960) Glucosamine metabolism. V. Enzymatic synthesis of glucosamine 6-phosphate. J Biol Chem 235: $1265-1273$

19. Badet-Denisot MA, Rene L, Badet B (1993) Mechanistic investigations on glucosamine-6- phosphate Synthase. Bull Soc Chim Fr 130: 249-255.

20. Massière F, Badet-Denisot MA (1998) The mechanism of glutamine-dependent amidotransferases. Cell Mol Life Sci 54: 205-222.

21. Kenchappa R, Yadav DB, Asha B, Sandeep T, Aruna Sindhe M (2014) synthesis, antimicrobial and antioxidant activity of benzofuran barbitone and benzofuran thiobarbitone derivatives. Med Chem Res 23: 3065-3081.

22. Kenchappa R, Bodke YD, Peethambar SK, Telkar S, Venkatesh KB (2013) Synthesis of b-amino carbonyl derivatives of coumarin and benzofuran and evaluation of their biological activity. Med Chem Res 22: 4787-4797.

23. Kenchappa R, Bodke YD, Chandrashekar A, Sandeep T, Manjunatha KS, et al. (2013) Synthesis of some 2, 6-bis (1-coumarin-2-yl)-4-(4-substituted-phenyl) pyridine derivatives as potent biological agents. Arab J Chem 23: 3065-3081.

24. Sheelavanth S, Bodke YD, Sundar SM (2013) Synthesis, antioxidant and antibacterial studies of phenolic esters and amides of 2-(1-benzofuran-2-yl) quinoline-4-carboxylic acid. Med Chem Res 22: 1163-1171.

25. Chandrashekar A, Eswarappa B, Bodke YD, Venkatesh KB, Raghu N, et al. (2013) 5-phenyl-1-benzofuran-2-yl derivatives: synthesis, antimicrobial, and antioxidant activity. Med Chem Res 22: 78-87.

26. Venkatesh KB, Bodke YD, Biradar SA (2010) Synthesis of 3-[4-(1-benzofuran2-yl)-1,3-thiazol-2-yl]-2-(4-Aryl)-1,3-thiazolidin-4-one derivatives as biological agents. Phosphorus, Sulfur Silicon Relat Elem 185: 1926-1931.

27. Venkatesh KB, Bodke YD, Biradar S, Kumara Swamy BE, Umesh S (2010) A facile synthesis of bromo-substituted benzofuran containing thiazolidinone nucleus bridged with quinoline derivatives potent analgesic and antimicrobial agents. Phosphorus, Sulfur Silicon Relat Elem 185: 110-116.

28. Khalil NS (2010) Efficient synthesis of novel 1,2,4-triazole fused acyclic and 21-28 membered macrocyclic and/or lariat macrocyclic oxaazathia crown compounds with potential antimicrobial activity. Eur J Med Chem 45: 5265-5277.
29. Villanova (1982) Standard methods for dilution antimicrobial susceptibility tests for bacteria, which grows aerobically. NCCLS.

30. Wallace DWR, Minnett PJ, Hopkins TS (1992) Nutrients, oxygen and inferred new production in the northeast water polynya. J Geoph Res 100: 4323-4340.

31. Binkowski TA, Naghibzadeh S, Liang J (2003) CASTp: Computed Atlas of Surface Topography of proteins. Nucleic Acids Res 31: 3352-3355.

32. Braca A, De Tommasi N, Di Bari L, Pizza C, Politi M, et al. (2001) Antioxidant principles from Bauhinia tarapotensis. J Nat Prod 64: 892-895.

33. Nevcihan G, Cengiz S, Bektas T, Halil SM (2010) Evaluation of antioxidant activities of three edible mushrooms; ramariaflava, rhizopoganroseolus and russuladelica. Food Sci Biotech 19: 691-696.

34. Kumar RS, Hemalatha S (2011) In vitro antioxidant activity of alcoholic leaf extract and subfractions of alangium lamarckii thwaites. J Chem Pharm Res 3: 259-267.

35. Nabila AAJ, Amal SAB, Makarem MSK (2012) Study of Michael addition on chalcones and or chalcone analogues. J Sau Chem Soci 16: 45-53.

36. Mor S, Pahal P, Narasimhan B (2012) Synthesis, characterization, antimicrobial activities and QSAR studies of some 10a-phenylbenzo[b]indeno[1,2-e][1,4] thiazin-11(10aH)-ones. Eur J Med Chem 53: 176-189.

37. Stefania FB, Gabriel S, Gabriela LA, Constantin D, Florica B, et al. (2012) New heterocyclic compounds From 1,2,4-triazole and 1,3,4-thiadiazole class bearing diphenyl sulfone moieties. Synthesis, characterization and antimicrobial activity evaluation. Eur J Med Chem 49: 417-42.

38. Lopez SN, Castelli MV, Zacchino SA, Dominguez JN, Lobo G, et al. (2001) In vitro antifungal evaluation and structure-activity relationships of a new series of chalcone derivatives and synthetic analogues with inhibitory properties against polymers of the fungal cell wall. Bio Med Chem 9: 1999-2013.

39. Sharma P, Rane N, Gurram VK (2004) Synthesis and QSAR studies of pyrimido[4,5-d]pyrimidine-2,5-dione derivatives as potential antimicrobial agents. Bioorg Med Chem Lett 14: 4185-4190.

40. Dhorajiya BD, Bhakhar BS, Dholakiya BZ (2012) Synthesis, characterization solvato chromic properties and antimicrobial evaluation of 5-acetyl-2-thioxodihydropyrimidine-4,6-dione-based chalcones. Med Chem Res 22: 4075-4086.

41. Shulaeva MM, Fattakhov SG, Saifina LF, Chestnova RV, Valijev RSh, etal. (2012) Synthesis and antimycobacterial activity of novel 1,3-dimethylisocyanurate derivatives. Eur J Med Chem 53: 300-307.

42. Milewski S (2002) Glucosamine-6-phosphate synthase--the multi-facets enzyme. Biochim Biophys Acta 1597: 173-192.

43. Paudel B, Bhattarai HD, Koh HY, Lee SG, Han SJ, et al. (2011) Ramalin, a novel nontoxic antioxidant compound from the Antarctic lichen Ramalina terebrata. Phytomedicine 18: 1285-1290.

44. Elmastas M, Gulçin I, Isildak O, Kufrevioglu OI, Ibaoglu K, et al. (2006) radical scavenging activity and antioxidant capacity of bay leaf extracts. J Iran Chem Soc 3: 258-266.

45. Nabavi SM, Ebrahimzadeh MA, Nabavi SF, Jafari M (2008) free radical scavenging activity and antioxidant capacity of eryngium caucasicum trautv and froripia subpinnata. Pharmacologyonline 3: 19-25. 